\title{
Pre-Service Preschool Teachers' Beliefs about Foreign Language Learning and Early Foreign Language Teaching in Slovenia
}

Mateja Dagarin Fojkar ${ }^{1}$ And Darija Skubic ${ }^{\star 2}$

$\approx$ The implementation of foreign languages in preschool education has prompted the need for qualified teachers. However, most recent studies report a gap between the supply of qualified foreign language teachers of young learners and the demand for such teachers as foreign languages are introduced earlier and earlier. The authors of this paper present some models of initial and in-service training of preschool foreign language teachers in Slovenia. As learners' beliefs about language learning have been considered an important variable, like many other individual differences in language learning, the main aim of the research was to determine pre-service preschool teachers' beliefs about early foreign language learning. The research was conducted on a sample of 90 pre-service preschool teachers. The results imply that future preschool teachers are aware of the importance of foreign language learning and their awareness raises with the year of study. The results of the survey indicate that it would be beneficial to include early foreign language teacher training in the education of preschool teachers who are willing to teach foreign languages in kindergartens in Slovenia and elsewhere.

Keywords: foreign language learning, preschool teachers, preschool teachers' beliefs, pre-service teacher training

1 University of Ljubljana, Faculty of Education, Slovenia.

$2{ }^{\star}$ Corresponding Author. University of Ljubljana, Faculty of Education, Slovenia; darija.skubic@pef.uni-lj.si. 


\section{Prepričanja študentov predšolske vzgoje o učenju in zgodnjem poučevanju tujega jezika v Sloveniji}

Mateja Dagarin Fojkar in Darija Skubic

$\propto$ Uvajanje učenja tujih jezikov v predšolski vzgoji in izobraževanju je spodbudilo potrebo po usposobljenih učiteljih. A večina študij, opravljenih pred kratkim, poroča o vrzeli med ponudbo usposobljenih učiteljev tujih jezikov mlajših učencev v zgodnjem obdobju in povpraševanjem po tovrstnih učiteljih zaradi vedno bolj zgodnjega uvajanja tujih jezikov v vzgojno-izobraževalni sistem. Avtorici tega prispevka predstavita nekaj modelov začetnega izobraževanja in nadaljnjega usposabljanja učiteljev tujih jezikov v predšolskem obdobju v Sloveniji. Prepričanja bodočih vzgojiteljev o učenju jezikov so bila upoštevana kot pomembna spremenljivka tako kot veliko drugih individualnih razlik v tujejezikovnem učenju, glavni cilj raziskave pa je bil ugotoviti, kakšna so prepričanja bodočih vzgojiteljev o zgodnjem učenju tujih jezikov. V raziskavo je bilo vključenih 90 bodočih vzgojiteljev. Rezultati kažejo, da se bodoči vzgojitelji zavedajo pomembnosti učenja tujih jezikov in da to zavedanje narašča z leti študija. Rezultati raziskave kažejo tudi, da bi bilo koristno vključiti usposabljanje za zgodnje učenje tujih jezikov v študijski program Predšolska vzgoja za tiste vzgojitelje, ki bi želeli učiti tuje jezike v vrtcih v Sloveniji in drugod po svetu.

Ključne besede: vzgojitelji, učenje tujih jezikov, usposabljanje bodočih vzgojiteljev, prepričanja vzgojiteljev 


\section{Introduction}

For a long time, parents and teachers have been worried that early-age bilingual exposure may impair and delay children's cognitive development. Yet, modern researchers state cognitive advantages for bilingual children. Research has shown for some time that bilingual children typically develop certain types of cognitive flexibility and metalinguistic awareness earlier and better than their monolingual peers (e.g., Bialystok, 2001; Cummins, 2000; King \& Mackey, 2007). The acquisition of two competing language systems creates a particularly strong demand for attentional and executive control (Costa, Hernández, \& Sebastián-Gallés, 2008). This need to control attention to the target system influences bilingual children both cognitively and linguistically. The study of cognitive styles - specifically, styles of learning and thinking - suggests that bilingualism alters the way that individuals conceptually structure information (Bialystok, 2001). According to Bialystok (2001, 2007), selective attention is one of the primary cognitive benefits of bilingualism. Bilingual children are less prone to suffer from a context of misleading information and complexity compared to monolinguals. Lauchlan, Parisi and Fadda's study (2012), in which bilingual children were compared to monolingual children in terms of cognitive control, problem-solving skills, metalinguistic awareness and working memory, confirms that bilingual children outperform monolingual children in each of these cognitive tests. Bilingual children differentiate their two languages and use code-mixing deliberately, already by the age of two (Meisel, 2004). Their ability to adapt to their surroundings and the context in which they use language indicates that code-mixing among bilingual children reflects the development of linguistic and socio-linguistic awareness (ibid.).

\section{Theoretical background}

The spread of foreign languages into early childhood education has created a need for qualified teachers. However, most recent studies (among them Emery, 2012; Enever, 2011; Enever \& Moon, 2009; Garton, Copland, \& Burns, 2011; Hayes, 2014; Murphy, 2014; Rixon, 2013) report that there is a gap between the supply of qualified foreign language teachers of young learners and the demand for such teachers as foreign languages are introduced earlier and earlier. These studies also emphasise the importance of assuring the quality of early foreign language instruction, despite the general assumption that teachers who teach young children do not need to have high qualifications. Hanušová and Najvar (2006, p. 7) even claim that "the younger the pupil [starting to learn L2], 
the more significant the qualification of the teacher". Nikolov and Mihaljević Djigunović (2011) explain that teachers of young learners need to be proficient in both the children's first language and the foreign language (hereinafter: FL), as well as having an in-depth knowledge of the content and curriculum, and at the same time being experts in teaching young learners and teaching languages in particular. The authors add that many teachers are unable to meet all of these expectations.

Children are, however, quite motivated to learn other languages. Brumen (2011) researched the perceptions of pre-school age children concerning foreign language learning motivation in Slovenia. She confirmed that children are intrinsically motivated in foreign language learning; they are satisfied with their accomplishments, they seek activities, and they are eager to acquire knowledge. An atmosphere of support is important to them, as is a stimulating environment and a feeling of security and comfort. When these elements are lacking, children typically want to learn less. This research only confirms the crucial role of preschool teachers in the learning process.

\section{Teacher training for preschool teachers teaching foreign languages}

Teacher training for preschool teachers who want to teach foreign languages in kindergarten is not very common in Europe. There are some short in-service programmes in France (Ellis, 2016) and Cyprus (Ioannou-Georgiou, 2015) that attempt to develop both preschool teachers' FL proficiency and FL teaching methodology, but teachers are largely left to work on these two skills autonomously, resulting in highly varied levels of expertise. Černà (2015, p. 174) describes the situation in the Czech Republic, stating that "qualification requirements remain unspecified for pre-primary teachers of English", while Portiková (2015) depicts a similar situation in Slovakia, where pre-primary English teachers are not required to have any special qualification in FL proficiency and methodology. The situation is, however, slightly different in Poland, where preschool teachers can attend a course in foreign language methodology (Rokita-Jaśkov, 2013).

In Slovenia, preschool teachers are required to have a BA degree and can teach children aged from one to five years (kindergarten) and in the first year of primary school (age six), but most preschool teachers are not trained to teach a foreign language. The level of their first FL, which is usually English, should be at $\mathrm{B}_{2}$ on passing the final secondary school leaving exam. Currently, there is an in-service teacher training programme for those who wish to gain a 
formal certificate to teach English to children (preschool and up to 11 years of age). The programme is very extensive, entailing 660 contact hours (6o ECTS) and focusing on both the development of preschool teachers' language skills and the methodology of teaching an FL to children. With a duration of two years, the programme is, however, very demanding, and therefore only a few preschool teachers have completed it. There is no formal FL training offered to pre-service preschool teachers in Slovenia. During their BA studies, students can only select an elective course of 4 ECTS (6o contact hours) for developing English language skills. Consequently, most preschool teachers are unable to teach English in kindergarten due to their lack of language skills and methodological knowledge. Nevertheless, research shows that in 2009/2010 almost half of Slovenian kindergartens (47.5\%) offered children some form of FL teaching, and we can assume that this number has grown in the last seven years. Teachers who teach an FL in kindergarten are still mostly FL specialist teachers who come once a week to give an FL lesson; they are typically not acquainted with the preschool curriculum and have not had much training in teaching children. Ideally, FLs would be taught by trained preschool teachers proficient in both the FL and in early language teaching methodology, and integrated into the kindergarten curriculum.

\section{Beliefs about language learning}

Beliefs about language learning belong in the domain of affective variables, such as attitudes, motivation, anxiety, etc. Assessing beliefs that language learners bring to the language classroom is important for both language instructors and curriculum designers because "beliefs are predispositions to action" (Rokeach, 1968, p. 113). Educational psychology supports the proposition of the importance of beliefs that learners hold as a defining factor of their learning behaviour.

Horwitz (1987, p. 120) defined beliefs about language learning as "opinions on a variety of issues and controversies related to language learning". Wenden considered learner beliefs as metacognitive knowledge from a wider perspective, and defined them as "learners' acquired knowledge about learning: the nature of learning, the learning process, and humans as learners, including themselves" (1999, p. 435).

Gardner (2005) claims that motivation is a multifaceted concept, involving cognitive, affective and behavioural components. Gardner's research (2005), in which the Attitude Motivation Test Battery (AMTB) was developed to measure the various components of the socio-educational model of second 
language acquisition, indicated clearly that if an individual is highly motivated to learn another language, has an open and accepting approach to other cultural groups and/or a strong emotional interest in the target language group, and has a positive evaluation of the learning situation, then we might describe that person as being integratively motivated to learn the language. We would probably also find that the person is very successful in learning and using the language.

In the past two decades, many researchers have explored language learning beliefs in various studies, covering several groups of learners in different settings of learning: foreign language learners and English as a foreign or second language (EFL/ESL) learners (e.g., Bernat, 2004; Diab, 2006; Horwitz, 1987, 1988; Kern, 1995; Loewen et al., 2009; Peacock, 2001; Riley, 2009). The situation reflects the potential impact of beliefs on language learning, and consequently on the outcome of learning (Abraham \& Vann, 1987; Mori, 1999; Tanaka \& Ellis, 2003).

\section{Reseach problem}

It has been recognised that beliefs about language learning are contextspecific, and that learners from different cultures may have different attitudes, approaches and opinions regarding learning a new language. Furthermore, as Fullan (2007) points out, whenever we plan an educational change (in our case, introducing an FL into the preschool period), all stakeholders need to be involved. With educational change, the roles and beliefs of teachers need to be researched thoroughly for successful implementation to take place. The main aim of this study was to investigate pre-service preschool teachers' beliefs about foreign language learning and early foreign language teaching in Slovenia. Our objective was to determine whether these teachers have a positive attitude towards early FL learning, and towards languages and language learning in general. We wanted to know whether they would be willing to teach FLs and under what conditions. We also enquired about their awareness of early FL learning strategies and the most appropriate methods for teaching FLs to preschool children. Furthermore, we asked the teachers about the importance of the FL proficiency level in teaching preschool children.

\section{Research questions}

The research questions of this study were as follows:

1. What are pre-service preschool teachers' beliefs about foreign language learning?

2. Are the beliefs about foreign language learning different between first-, second- and third-year students? 
3. What are pre-service preschool teachers' beliefs about early foreign language learning and teaching?

4. Are the beliefs about the proficiency level required by preschools teachers who teach an FL in kindergarten different between first-, secondand third-year students?

5. What are preschool teachers' opinions regarding the most important attributes in teaching FLs to children (e.g., proficient knowledge of the FL, teaching experience, FL methodology knowledge, teacher's personality)?

\section{Sample}

A total of 90 students of the first-cycle university programme Preschool Education participated in the study. Since we wanted to investigate whether preschool teachers' beliefs vary with the year of study, we included students from Year 1 (first year of studies) to Year 3 (final year of studies). The study included 43 students (47.8\%) from the first year of study, 37 (41.1\%) from the second year, and 10 (11.1\%) from the third year. The students were all studying at the Faculty of Education, University of Ljubljana, Slovenia. Their ages ranged from 19 (Year 1) to 21 (Year 3).

\section{Instrument}

The data were collected in June 2015 at the Faculty of Education, University of Ljubljana. For the purpose of the study, a questionnaire was developed by the authors, based on a literature review of prevailing beliefs about early language learning and language teaching. Since the existing instruments mainly explore language teachers' beliefs rather than those of pre-school teachers, the authors decided to use their own instrument, which is more focused on this specific group. The questions were related to some of the most relevant second language acquisition theories regarding young learners and methodologies on how to teach languages to young learners. Among them, we considered Vygotsky's theory on language development and sociocultural theory, which also describes how cultural beliefs and attitudes impact the manner in which instruction and learning take place (1986); Gardner's theory on integrative motivation (1985); Krashen and Terrell's natural approach, which focuses on developing communicative skills through extensive exposure to FL input and engaging activities in an anxiety-free environment (1983); the communicative approach with its focus on real interaction (Richards \& Rodgers, 2001); language immersion theory in which the learners' FL is the medium of classroom instruction and which fosters bilingualism (Baker, 1993); and task-based learning, where students complete meaningful tasks (Willis, 1996). 
In addition to drawing on this literature, the authors interviewed preservice preschool teachers about their beliefs regarding language learning and teaching, and these interviews were used as a further source of items used in the study. Eventually, drawing from these two sources, a 19-item questionnaire was developed, with 17 belief scale items and 2 questions with closed response alternatives. The questionnaire was designed according to two main concepts: pre-service preschool teachers' beliefs about FL learning in general (6 statements) and pre-service preschool teachers' beliefs about early foreign language learning and teaching (10 statements and 2 questions with closed response alternatives). The questionnaire items were found to be highly reliable (Cronbach's $\alpha=.83$ ).

\section{Data analysis}

After verifying that the data were free from errors, matrix analyses were conducted using IBM SPSS Statistics software. The data were controlled according to the assumptions of normal distribution, homogeneity of variance, and expected counts. In view of the research questions, mainly descriptive (absolute frequency, percentage, mean, standard deviation) procedures and statistical tests (one-way analysis of variance, post-hoc comparison, and Pearson's chi-square test with adjusted standardised residual) were applied. Partial etasquared and Cramer's V were calculated as a measure of effect size (Coolican, 2009).

\section{Results}

The results are presented in two sections. The first section shows the future preschool teachers' beliefs about FL learning in general, while the second section shows their beliefs about learning and teaching and learning foreign languages at preschool level (ages 1-6).

\section{Pre-service preschool teachers' beliefs about FL learning}

Future preschool teachers had to state their agreement or disagreement with statements related to language learning (1 - strongly disagree, 2 - disagree, 3 - can't decide, 4 - agree, and 5 - strongly agree). 
Table 1

Pre-service preschool teachers' beliefs about FL learning

\begin{tabular}{lcc}
\hline Statements & $\overline{\mathrm{x}}$ & SD \\
\hline $\begin{array}{l}\text { 1. Language is the most powerful tool in the development of any human being. } \\
\text { It is undeniably the greatest asset we possess (Vygotsky, 1986). }\end{array}$ & 4.32 .67 \\
\hline $\begin{array}{l}\text { 2. The motivation to learn a foreign language is determined by basic predisposi- } \\
\text { tions and personality characteristics, such as the learner's attitudes towards } \\
\text { foreign people in general and the target group in particular, as well as motives } \\
\text { for learning and generalised attitudes (Gardner, 1985). }\end{array}$ & 3.59 & .96 \\
\hline $\begin{array}{l}\text { 3. The use of a foreign language can detract from cultural identity. } \\
\text { 4. Slovenian students of preschool education are aware of the importance of }\end{array}$ & 2.12 & 1.00 \\
their proficiency level in English. & 3.83 & .97 \\
\hline $\begin{array}{l}\text { 5. Slovenian students of preschool education should take English as an obliga- } \\
\text { tory course, not just an elective one. }\end{array}$ & 3.33 & 1.36 \\
\hline $\begin{array}{l}\text { 6. It is important to be bilingual, i.e., to understand and speak two languages, } \\
\text { not necessarily with the same degree of fluency. }\end{array}$ & 4.11 & .92 \\
\hline
\end{tabular}

Note. $\mathrm{n}=90$.

Table 1 presents pre-service preschool teachers' beliefs about FL learning. The highest level of agreement is demonstrated with regard to the first statement, with $43.3 \%$ of all respondents completely agreeing with Vygotsky's statement on the importance of language (1986). One way analysis of variance showed that there is a statistically significant difference between groups of students in the beliefs with regard to the first statement $(F=3.481, p=0.035)$. The effect size measured with partial eta-squared is medium $(\eta 2=0.074, p=0.029)$. Hochberg post-hoc comparison test indicated a statistical significant difference between second- and third-year students, with third-year students $(\bar{x}=4.80)$ agreeing with the statement more than second-year students $(\overline{\mathrm{x}}=4 \cdot 19)$.

Most of the students agree with statement number six, that it is important to be bilingual, and a large number of them completely agree with this idea (40\%), whereas none of them (0.0\%) completely disagree. One way analysis of variance showed that there is a significant difference between groups of students $(\mathrm{F}=7.940, \mathrm{p}=0.001)$. The effect size measured with partial eta-squared is medium ( $\left.\eta_{2}=0.107, \mathrm{p}=0.000\right)$. Games-Howell post-hoc comparison test showed that there is a significant statistical difference between first- and thirdyear students, and between second and third-year students, with third-year students agreeing with the statement more $(\overline{\mathrm{x}}=4.90)$ than first- $(\overline{\mathrm{x}}=3.91)$ and second-year $(\overline{\mathrm{x}}=4.14)$ students.

Similarly, most of the students agree with the fourth statement that Slovenian students of preschool education are aware of the importance of their proficiency level in English $(\overline{\mathrm{x}}=3.83)$. 
Gardner's statement about motivation also gained quite a high level of agreement (statement No. 2), with $20 \%$ of all respondents completely agreeing with the statement and none of the respondents completely disagreeing. Some $\mathbf{2 4 . 4 \%}$ of all respondents completely agree with the statement that Slovenian students of preschool education should take English as an obligatory course, not just as an elective course (statement No. 5), whereas $15.6 \%$ of all respondents completely disagree with this statement. Further analysis showed that there is a statistically significant difference in the estimates between first- $(\overline{\mathrm{x}}=2.77)$ and third-year students $(\overline{\mathrm{x}}=4.00)$, indicating that third-year students agree with the statement more than first-year students. The effect size is large $\left(\eta^{2}=0.162\right.$, Games-Howell test $\mathrm{P}=0.050$ ).

In general, students disagree with the third statement that the use of a foreign language can detract from cultural identity, with only $4.4 \%$ of all respondents completely agreeing, and $27.8 \%$ of all respondents completely disagreeing.

\section{Pre-service preschool teachers' beliefs about early foreign language learning and teaching}

Table 2

Proficiency level required by a preschool teacher who teaches an FL in kindergarten

\begin{tabular}{lcc}
\hline Level & $\mathbf{F}$ & $\%$ \\
\hline B1 & 11 & 12.2 \\
B2 & 45 & 50.0 \\
C1 & 34 & 37.8 \\
\hline Total & 90 & 100.0 \\
\hline
\end{tabular}

Table 2 presents students' beliefs about the proficiency level required by a preschool teacher who teaches an FL in kindergarten. Half of all respondents (50\%) think that preschool teachers who teach an FL in kindergarten should have a proficiency level of $\mathrm{B}_{2}$, while $37.8 \%$ believe that a $\mathrm{C}_{1}$ level is required, and only a minority of respondents (12.2\%) are of the opinion that $\mathrm{B} 1$ is an adequate level for FL teachers at preschool level. Surprisingly, further analysis showed that, compared to students of the second and the third years, first-year students think a higher level of FL proficiency is required (51.2\% $\mathrm{C}_{1}$ and $\left.39.5 \% \mathrm{~B}_{2}\right)$. 
Table 3

Preschool teachers' opinions regarding the most important attributes in teaching FLs to children

\begin{tabular}{lcc}
\hline The most important attributes & $\mathbf{f}$ & $\%$ \\
\hline Proficient knowledge of the FL & 12 & 13.3 \\
Teaching experience & 19 & 21.1 \\
FL methodology knowledge & 59 & 65.6 \\
Personality (e.g., an understanding teacher) & 0 & 0 \\
Other & 0 & 0 \\
\hline Total & 90 & 100.0 \\
\hline
\end{tabular}

Table 3 displays pre-service preschool teachers' opinions regarding the most important attributes in teaching FLs to children. Some $65.6 \%$ of all respondents selected FL methodology knowledge as the most important attribute in teaching an FL to children, while $21.1 \%$ chose teaching experience as the most important characteristic and $13.3 \%$ regarded a proficient knowledge of the FL to be the most important aspect of teaching an FL to children. None of the respondents judge that personality is the most important quality in teaching an FL to children. -

In addition, pre-service preschool teachers were asked to state their level of agreement with certain statements regarding early foreign language learning (1 - strongly disagree, 2 - disagree, 3 - can't decide, 4 - agree, and 5 - strongly agree).

Table 4

Pre-service preschool teachers' beliefs about early foreign language learning and teaching

\begin{tabular}{lcc}
\hline Statement & X & S \\
\hline $\begin{array}{l}\text { 7. Appropriate strategies for supporting young children learning a foreign language } \\
\text { are: reading and telling stories every day, introducing vocabulary, playing word } \\
\text { games, connecting words to actions and objects, engaging in conversations, play- } \\
\text { ing games, learning rhymes and songs, modelling and expanding conversations. }\end{array}$ & 4.46 & .67 \\
\hline $\begin{array}{l}\text { 8. While using an FL, children develop social skills such as cooperating, helping, } \\
\text { negotiating and talking with other students to share messages. }\end{array}$ & 4.00 & .79 \\
\hline $\begin{array}{l}\text { 9. Children will become more tolerant towards other cultures and otherness if they } \\
\text { get to know (an)other language(s). }\end{array}$ & 3.64 & .96 \\
\hline $\begin{array}{l}\text { 10. Children's mother tongue will develop more slowly if they learn foreign lan- } \\
\text { guages in preschool. }\end{array}$ & 1.73 .87 \\
\hline $\begin{array}{l}\text { 11. Learning an FL should be one of the curriculum goals in the Slovenian National } \\
\text { Curriculum for kindergartens. }\end{array}$ & 2.91 .99 \\
\hline $\begin{array}{l}\text { 12. An FL should be integrated into the everyday activities of children at kindergar- } \\
\text { ten and not taught as an extracurricular activity once a week. }\end{array}$ & 2.91 .99 \\
\hline
\end{tabular}




\begin{tabular}{lcc}
\hline Statement & $\mathrm{x}$ & $\mathrm{S}$ \\
\hline $\begin{array}{l}\text { 13. An FL in kindergarten should be taught by a preschool teacher proficient in the } \\
\text { FL (at least B2 level). }\end{array}$ & 4.12 .99 \\
\hline $\begin{array}{l}\text { 14. Children should start learning an FL in kindergarten through game-like activities. } \\
\text { 15. The preschool teacher's attitude to learning an FL has an effect on children's }\end{array}$ & .30 \\
\hline $\begin{array}{l}\text { learning of the FL. } \\
\text { 16. I would be willing to teach an FL in kindergarten, provided I had the skills to do } \\
\text { so. }\end{array}$ & 4.43 & .80 \\
\hline
\end{tabular}

Table 4 shows pre-service preschool teachers' beliefs about early foreign language learning and teaching. The statement that FL learning should be in the form of game-like activities (statement No. 14) gained the most unanimous agreement among the respondents $(\overline{\mathrm{x}}=4.90): 13.3 \%$ of all respondents completely agree with this statement and 8.9\% completely disagree. Similarly, 55.6\% of all respondents completely agree with the statement that appropriate strategies for supporting young children learning a foreign language include stories, games and songs (statement No. 7), while none of the respondents (0.0\%) completely disagree with this statement. Some $55.6 \%$ of all respondents completely agree $(\overline{\mathrm{x}}=4.43)$ with the statement that they would be willing to teach an FL in kindergarten, provided they had skills to do so (statement No. 16). A high percentage of students also agree that the preschool teacher's attitudes to learning an FL have an effect on children's learning of an FL (statement No. 15), with $90.0 \%$ of the respondents completely agreeing with the statement, and that while using an FL children develop social skills as well (statement No. 8) $(\overline{\mathrm{x}}=4.00)$.

Most of the pre-service preschool teachers are in favour of the idea of FLs being taught by preschool teachers and not external FL teachers (statement No. 13), with $42.2 \%$ of all respondents completely agreeing with the statement and $1.1 \%$ completely disagreeing. The participants could not decide whether children will become more tolerant towards other cultures and otherness if they get to know other language(s) (statement No. 9) $(\overline{\mathrm{x}}=3.64): 16.7 \%$ of the respondents completely agree with the statement and $2.2 \%$ completely disagree. Only $1.1 \%$ of all respondents completely agree with statement No. 10 that the children's mother tongue will develop more slowly if they learn foreign languages in preschool, whereas $46.7 \%$ completely disagree with this statement. One way analysis of variance showed that there is a significant difference between groups of students $(\mathrm{F}=4.318, \mathrm{p}=0.016)$. The effect size measured with partial-eta squared is medium $\left(\eta_{2}=0.090, p=0.030\right)$. Hochberg post-hoc comparison test showed that there is a statistically significant difference in the estimates between first- and third-year students, with third-year students $(\overline{\mathrm{x}}=1.2 \mathrm{O})$ agreeing with the statement less than first-year students $(\overline{\mathrm{x}}=1.98)$.

Pre-service preschool teachers are undecided regarding whether learning 
an FL should be one of the curriculum goals in the National Curriculum for kindergartens (statement No. 11) $(\overline{\mathrm{x}}=2.91): 6.7 \%$ completely agree with the statement, while the same percentage $(6.7 \%)$ completely disagree. Further analysis again showed a statistically significant difference between first- $(\overline{\mathrm{x}}=2.77)$ and third-year students $(\overline{\mathrm{x}}=3.60)$. The effect size is medium $\left(\eta^{2}=0.090\right.$, Hochberg test, $\mathrm{P}=0.040$ ).

The surveyed participants are equally undecided $(\overline{\mathrm{x}}=2.91)$ with regard to statement No. 12 that FLs should be integrated into everyday kindergarten activities rather than being taught as an extracurricular activity, with 5.6\% of respondents completely agreeing with the statement and $7.8 \%$ completely disagreeing.

\section{Discussion}

Regarding the first research question (What are pre-service preschool teachers' beliefs about foreign language learning?), the present study demonstrates that the surveyed Slovenian students believe in the benefits of knowing more than one language. The students strongly believe that the preschool teacher's attitude towards learning an FL has an effect on children's learning of the FL, and, encouragingly, their beliefs about FL learning are positive. Hayes (2014) stated among his study recommendations that teachers should demonstrate positive attitudes towards English language learning, which in turn influences children's motivation to learn and their achievements.

With reference to the second research question (Are the beliefs about foreign language learning different between first-, second- and third-year students?), the awareness of the benefits of knowing more than one language increases with the year of study. Similarly, third-year students are more in favour of English being an obligatory course during their studies and think that it is important to be bilingual. Apparently, third-year students are more aware of the fact that foreign languages are taught at kindergartens, and that FL teachers are needed at this level of education.

With respect to the third research question, (What are pre-service preschool teachers' beliefs about early foreign language learning and teaching?), students think that FL teaching at preschool level should be done through game-like activities and with the use of songs, rhymes and stories. This is in line with the findings of other researchers working on early FL learning methodology (Enever, 2011; Mourão \& Lourenço, 2015; Robinson, Mourão, \& Nam Joon Kang, 2015). Learning through play is not merely a cognitive process, but also a cultural, emotional, social and physical process (Hyvönen, 2008). Nevertheless, researchers still point to a lack of play and playful methods in schools 
and early childhood education (e.g., Bergen, 2009; Pui-Wah, 2010), with some specifically pointing out the poor integration of play with the curriculum (Lord \& McFarland, 2010). Pramling, Samuelsson and Carlsson (2008) are also concerned about insufficient integration of play into the curriculum, claiming that, in preschool, the act of learning (how children play) has so far been much more the focus than the object of learning (what children learn). Future Slovenian preschool teachers also believe that children will gain social skills through FL learning and will become more tolerant towards other cultures. It is unequivocally accepted among experts that children learning languages develop intercultural competence as well as linguistic competence; as Byram, Gribkova and Starkey (2002, p. 10) put it:

Language learning prepares [children] for interaction with people of other cultures, it enables them to understand and accept people from other cultures as individuals with other distinctive perspectives, values and behaviours; and it helps them to see that such interaction is an enriching experience.

The students surveyed mostly disagree with the notion of learning FLs being part of the National Curriculum for preschool institutions. Further analysis showed a statistically significant difference between first- and third-year students, with third-year students disagreeing less than first-year students. Among the curriculum goals there are also goals such as: to create opportunities for lifelong learning, to reinforce opportunities for learning, motivation and joy of learning, and to support children's growth as human individuals and ethically responsible members of society who comply with generally accepted rules and who appreciate other people (National Curriculum for preschool institutions, 1999). Learning other languages and getting to know other cultures is the most appropriate way of achieving these goals. Not only can young children begin to acquire more than one language in their early years, but growing evidence also shows that early bilingualism can provide children with benefits that go beyond knowing more than one language. As agreed by other preschool experts, an FL would ideally be integrated into the curriculum. Poland, for instance, will commence FL learning from the age of three in 2017; at the moment, $80 \%$ of kindergartens already offer some form of FL learning to children (RokitaJaśkov, 2015). Similarly, there is rapid growth of voluntary FL introduction at preschool level in countries across Europe, e.g., in Italy, the Netherlands and Spain (Early Language Learning Country Summaries, 2011). However, teachers would have to be trained for performing FL activities and would require a high FL proficiency level. It is possible that the surveyed students are aware of these 
two conditions and cannot imagine this scale of FL implementation.

As regards the fourth research question (Are the beliefs about the proficiency level required by preschools teachers who teach an FL in kindergarten different between first-, second- and third-year students?), the study demonstrates that, contrary to the outcome of the second research question, first-year students think a higher level of FL proficiency is required. This shows that younger generations are more aware of the importance of a high level of language proficiency. Having a high FL proficiency level is a condition stated in other research, as well; for example, Enever (2011) stated in the Ellie Report that $\mathrm{C}_{1}$ is the desirable FL level for teaching young learners, while the Slovenian in-service programme for teaching an FL to young learners aims at teachers having $\mathrm{C} 1$ level upon the completion of the programme (Brumen, \& Dagarin Fojkar, 2012). Similarly, Hayes (2014) reports that teachers teaching young learners should have an English level of at least B2, and preferably C1. However, the reality is different from the recommendations. Butler (2004) has revealed that there is a substantial gap between the English proficiency level of primary school teachers in some Asian countries and the level they need to teach. Analogously, Černà (2015) reports about the situation in the Czech Republic, where preschool teachers can teach English despite having reached only B1 or A2 level.

With regard to the fifth research question (What are preschool teachers' opinions regarding the most important attributes in teaching FLs to children (e.g., proficient knowledge of the FL, teaching experience, FL methodology knowledge, teacher's personality), the study reveals that FL methodology was selected as the most important attribute in teaching an FL to children. Indeed, the knowledge of an appropriate methodology for working with children has been emphasised in other studies (e.g., Nikolov \& Mihaljević Djigunović, 2011; Hayes, 2014). Furthermore, Kelly et al. (2004) claim that foreign language education in the $21^{\text {st }}$ century should, among others, include training in language teaching methodologies and in state-of-the-art classroom techniques and activities, since "trainee teachers who learn about a number of methodological approaches to teaching and learning are able to adapt to particular contexts, and have a firm foundation for the critical and creative use of teaching theories" (p. 46).

\section{Conclusion}

A platform of international declarations and conventions supports the learning of at least two languages in education - the mother tongue and the language of the larger community - as well as access to international languages. In its 2003 position paper, Education in a Multilingual World, UNESCO (2003, 
p. 27) espouses "mother tongue instruction as a means of improving educational quality by building on the knowledge and experience of the learners and teachers; bilingual and/or multilingual education at all levels of education as a means of promoting both social and gender equality and as a key element of linguistically diverse societies; language as an essential component of intercultural education to encourage understanding between different population groups and ensure respect for fundamental rights". Language learning brings many pluricultural benefits to children, who will grow up into multilingual and multicultural individuals. However, in order to be exposed to multiculturalism and multilingualism from an early age, children need to be taught by openminded and well-educated (preschool) teachers. Slovenian preschool students are willing to teach foreign languages in kindergarten, but they are aware of the fact that they need further training in order to upgrade their FL methodology knowledge and FL skills. We believe that they will gradually have an opportunity to do so, but as it involves the most vulnerable group - children - this innovation needs time and thorough consideration of all of the factors involved.

\section{References}

Abraham, R. G., \& Vann, R. J. (1987). Strategies of two language learners: A case study. In A. Wenden \& J. Rubin (Eds.), Learner strategies in language learning (pp. 85-102). London, UK: Prentice-Hall.

Baker, C. (1993). Foundations of bilingual education and bilingualism. Clevedon, UK: Multilingual Matters. Bergen, D. (2009). Play as the learning medium for future scientists, mathematicians, and engineers. American Journal of Play, 1(4), 413-428.

Bernat, E. (2004). Investigating Vietnamese ESL learners' beliefs about language learning. EA Journal, 21(2), 40-54. Retrieved from http://www.englishaustralia.com.au /index.cgi? $\mathrm{E}=$ hsshowjnl\&efile=admi $\mathrm{n} \& \mathrm{M}=\operatorname{art} \& \mathrm{X}=$ getdoc $\&$ Lev $1=5 \& \operatorname{Lev} 2=3 \& \operatorname{Lev} 3=4$

Bialystok, E. (2001). Bilingualism in development: Language, literacy, and cognition. New York, NY: Cambridge University Press.

Bialystok, E. (2007). Cognitive effects of bilingualism: How linguistic experience leads to cognitive change. International Journal of Bilingual Education and Bilingualism, 10(3), 210-223. Retrieved from http://dx.doi.org/10.2167/beb441.o

Brumen, M. (2011). The perception of and motivation for foreign language learning in preschool. Early Child Development and Care. 181(6), 717-732.

Brumen, M., \& Dagarin Fojkar, M. (2012). Teacher development in Slovenia for teaching foreign languages at the primary level. CEPS Journal, 2(3), 27-53.

Butler, Y. G. (2004). What level of English proficiency do elementary teachers need to attain to teach EFL? Case studies from Korea, Taiwan, and Japan. TESOL Quarterly, 38(2), 245-287.

Byram, M., Gribkova, B., \& Starkey, H. (2002). Developing the intercultural dimension in language 
teaching: A practical introduction for teachers. Strasbourg: Language Policy Division. Directorate of School, Out-of-School and Higher Education DGIV. Strasbourg: Council of Europe.

Coolican, H. (2009). Research methods and statistics in psychology (5th ed.). London, UK: Hodder Education.

Costa, A., Hernández, M., \& Sebastián-Gallés, N. (2008). Bilingualism aids conflict resolution: Evidence from the ANT task. Cognition, 106(1), 59-86.

Cummins, J. (2000). Language, power and pedagogy. Clevedon, UK: Multilingual Matters.

Černà, M. (2015). Pre-primary English language learning and teacher education in the Czech Republic. In S. Mourão \& M. Lourenço (Eds.), Early years second language education: International perspectives on theory and practice (pp. 165-176). Abingdon, UK: Routledge.

Diab, R. L. (2006). University students' beliefs about learning English and French in Lebanon. System, $34(1), 80-96$.

Early Language Learning Country Summaries. (2011). Retrieved 20.11.2015 from http://ec.europa.eu/ languages/policy/learning-languages/early-language-learning_en.htm.

Ellis, G. (2016). A short, in-service training course for pre-school teachers in France. In V. A. Murphy \& M. Evangelou (Eds.), Early Childhood Education in English for Speakers of Other Languages (pp. 265-278). London, UK: British Council.

Emery, H. (2012). A global study of primary English teachers' qualifications, training and career development. ELT Research Papers 12-08. London, UK: British Council.

Enever, J. (Ed.). (2011). ELLiE. Early language learning in Europe. London, UK: British Council.

Enever, J., \& Moon, J. (2009). New global contexts for teaching Primary ELT: Change and challenge. In J. Enever, J. Moon, \& U. Raman (Eds.), Young learner English language policy and implementation: International perspectives (pp. 5-21). Reading, UK: Garnet Education.

Enever, J., Moon, J., \& Raman, U. (Eds.) (2009). Young learner English language policy and implementation: International perspectives. Reading, UK: Garnet Education.

Fullan, M. (2007). The new meaning of educational change (4th ed.). New York, NY: Teachers College Press.

Gardner, R. C. (1985). Social psychology and second language learning: The role of attitudes and motivation. London, UK: Edward Arnold Publishers.

Gardner, R. C. (2005). Integrative motivation and second language acquisition. Canadian Association of Applied Linguistics/Canadian Linguistics Association Joint Plenary Talk - 30 May 2005, London, Canada. Retrieved from http://publish.uwo.ca/ \%2ogardner/docs/caaltalksfinal.pdf

Garton, S., Copland, F., \& Burns, A. (2011). Investigating global practices in teaching English to young learners. London, UK: British Council.

Hanušová, S., \& Najvar, P. (2006). Foreign language acquisition at an early age. Proceedings from the conference organised and hosted by Faculty of Education, Masaryk University on 16 March 2006. Brno: Masaryk University.

Hayes, D. (2014). Factors influencing success in teaching English in state primary schools. London, UK: British Council. 
Horwitz, E. K. (1987). Surveying student beliefs about language learning. In A. Wenden \& J. Rubin (Eds.), Learner strategies in language learning (pp. 119-129). London, UK: Prentice-Hall.

Horwitz, E. K. (1988). The beliefs about language learning of beginning university foreign language students. The Modern Language Journal, 72(3), 283-294.

Hyvönen, P. (2008). Affordances of playful learning environment for tutoring playing and learning. Unpublished doctoral dissertation. Acta Universitatis Lappoensis 152 . University of Lapland, Faculty of Education, Finland.

Ioannou-Georgiou, S. (2015). Early language learning in Cyprus: voices from the classroom. In S. Mourão \& M. Lourenço (Eds), Early years second language education: International perspectives on theory and practice (pp. 95-108). Abingdon: Routledge.

Kelly, M., Grenfell, M., Allan, R., Kriza, C., \& McEvoy, W. (2004). European profile for language teacher education: A frame of reference. Southampton, UK: University of Southampton.

King, K., \& Mackey, A. (2007). The bilingual edge: Why, when, and how to teach your child a second language. New York, NY: Collins.

Krashen, S. D., \& Terrell, T. D. (1983). The natural approach: Language acquisition in the classroom. Oxford, UK: Pergamon Press.

Lauchlan, F., Parisi, M., \& Fadda, R. (2012). Bilingualism in Sardinia and Scotland: Exploring the cognitive benefits of speaking a 'minority' language. International Journal of Bilingualism, 17(1), 43-56. Lord, A., \& McFarland, L. (2010). Pre-service primary teachers' perceptions of early childhood philosophy and pedagogy: A case study examination. Australian Journal of Teacher Education, 35(3), $1-113$.

Kern, R. G. (1995). Students' and teachers' beliefs about language learning. Foreign Languages Annals, 28(1), 71-92.

Loewen, S., Li, S., Fei, F., Thompson, A., Nakatsukasa, K., Ahn, S., \& Chen, X. (2009). Second language learners' beliefs about grammar instruction and error correction. The Modern Language Journal, 93(1), 91-104.

Meisel, J. (2004). The bilingual child. In T. K. Bhatia \& W. C. Ritchie (Eds.), The handbook of bilingualism (pp. 91-113). Malden, MA: Blackwell Publishing. Retrieved from http://www1.unihamburg.de/romanistik/personal/pdf-Dateien/bilchild.pdf

Mori, Y. (1999). Epistemological beliefs and language learning beliefs: What do language learners believe about their learning? Language Learning, 49(3), 377-415.

Mourão, S., \& Lourenço, M. (2015). Early years second language education: International perspectives on theory and practice. Abingdon, UK: Routledge.

Murphy, V. A. (2014). Second language learning in the early school years: Trends and contexts. Oxford, UK: OUP.

National curriculum for preschool institutions (1999). Ljubljana: Ministry of Education and Sport, National Education Institute Slovenia.

Nikolov, M., \& Mihaljević Djigunović, J. (2011). All shades of every colour: an overview of early teaching and learning of foreign languages. Annual Review of Applied Linguistics, 31, 95-119. 
Peacock, M. (2001). Pre-service ESL teachers' beliefs about second language learning: a longitudinal study. System, 29(2), 177-195.

Pui-Wah, D. (2010). Exploring the tactfulness of implementing play in the classroom: A Hong Kong experience. Asia-Pacific Journal of Teacher Education, 38(1), 69-82.

Portiková, Z. (2015). Pre-primary second language education in Slovakia and the role of teacher training programmes. In S. Mourão \& M. Lourenço (Eds.), Early years second language education: International perspectives on theory and practice (pp. 177-188). Abingdon: Routledge.

Pramling Samuelsson, I., \& Asplund, M. C. (2008). The playing learning child: Towards a pedagogy of early childhood. Scandinavian Journal of Educational Research, 52(6), 623-641.

Richards, J. C., \& Rodgers, T. S. (2001). Approaches and methods in language teaching (2nd ed.). Cambridge, UK \& New York, NY: Cambridge University Press.

Riley, P. A. (2009). Shifts in beliefs about second language learning. RELC Journal, 40(1), 102-124.

Rixon, S. (2013). British Council Survey of Policy and Practice in Primary English Language Teaching Worldwide. London, UK: British Council.

Robinson, P., Mourão, S., \& Joon Kang, N. (2015). English learning areas in pre-primary classrooms: an investigation of their effectiveness. London, UK: British Council.

Rokeach, M. (1968). Beliefs, attitudes, and values: A theory of organization and change. San Francisco, CA: Jossey-Bass.

Rokita-Jaśkow, J. (2013). Foreign language learning at pre-primary level: Parental aspirations and educational practice. Kraków: Pedagogical University Press.

Rokita-Jaśkow, J. (2015). Parental visions of their children's future as a motivator for an early start in a foreign language. Studies in Second Language Learning and Teaching, 5(3), 455-472.

Tanaka, K., \& Ellis, R. (2003). Study-abroad, language proficiency, and learner beliefs about language learning. JALT Journal, 25(1), 63-85. Retrieved from http://www.jalt-publications.org/archive/jj/2003a/ art3.pdf

UNESCO (2003). Education in a multilingual world. UNESCO Education Position Paper. Paris:

UNESCO. Retrieved from http://unesdoc.unesco.org/images/o012/o01297/129728e.pdf

Vygotsky, L. (1986). Thought and language (2nd ed.). Massachusetts, MA: MIT Press.

Wenden, A. L. (1999). An introduction to metacognitive knowledge and beliefs in language learning: beyond the basics. System, $27(4), 435-441$.

Willis J. (1996). A framework for task-based learning. Harlow, UK: Longman Pearson Education. 


\section{Biographical note}

Mateja Dagarin Fojkar, PhD, is Assistant Professor of English Language Teaching Methodology at the Faculty of Education, University of Ljubljana, Slovenia and holds a $\mathrm{PhD}$ in teaching English to young learners. Her main research areas include teaching foreign languages to young learners and developing communication and literacy skills in beginner learners of additional languages.

DARIJA Skubic, PhD, is Assistant Professor of Slovene Language Teaching Methodology at the Faculty of Education, University of Ljubljana, Slovenia. She holds a PhD in teaching the methodology of Slovene language. Her main research areas include developing pre-literacy skills in preschool children and Slovene as a second/foreign language in preschool institutions and primary schools. 